\title{
PENGARUH HARGA DAN KUALITAS PRODUK TERHADAP KEPUTUSAN PEMBELIAN KONSUMEN PADA PENGGUNA SEPEDA MOTOR PULSAR KAWASAKI DIKOTA PADANG
}

\author{
Syafral Hafiz, Aminar Sutra Dewi \\ Sekolah Tinggi Ilmu Ekonomi KBP \\ syafralhafiz@gmail.com
}

\begin{abstract}
This research was based by a decrease in sales of motorcycle Kawasaki Pulsar 200 NS within the first half in 2015-2016. The sales decline is one indication of a decrease in consumer purchasing decisions against the Kawasaki Pulsar 200 NS products. This research aimed to examine the effect of the price and product quality, purchase decision sport motorcycle Kawasaki Pulsar 200 NS. This research used purposive sampling method, using a sample of 100 people from the user population Kawasaki Pulsar 200 NS users in the city of Padang. The analytical method used is multiple linear regression. The results of this research reported the following regression equation: $Y=0,389+0,240 \mathrm{X}_{1}+0,629 \mathrm{X}_{2}$. Based on statistical data analysis, indicators in this research are valid and reliable. On the classical assumption test, regression models multicoloniarity free, does not occur heteroscedasticity, and the normal distribution. The biggest variable is the variable quality of the product which 0.629. whereas the smallest variable is the variable price which 0.240. Results of the research found that all independent variables are positive and has significant effect on the dependent variable.
\end{abstract}

Keywords: Price, Quality Product and Purchase Decision

\section{PENDAHULUAN}

Pesatnya perkembangan industri ini disebabkan banyaknya jumlah penduduk negara ini, Dan merupakan pasar yang berpotensial bagi perkembangan industri pada umumnya. Dari sekian banyak alat transportasi yang berguna dalam membantu aktivitas manusia sehari-hari, sepeda motor merupakan pilihan yang utama, karena sepeda motor tidak hanya terbatas dikalangan remaja saja tetapi lebih bersifat universal. Berikut ini adalah daftar penjualan sepeda motor di kota Padang pada bulan Agustus 2015 sampai Agustus 2016. 
Tabel 1

Daftar Penjualan Motor di Kota Padang Agustus 2015 - Agustus 2016

\begin{tabular}{|c|l|r|l|}
\hline No & \multicolumn{1}{|c|}{ Merk } & Total Unit Penjualan & \multicolumn{1}{c|}{ Ket } \\
\hline 1 & Honda & 77.566 & \\
\hline 2 & Yamaha & 23.543 & \\
\hline 3 & Suzuki & 1.590 & \\
\hline 4 & Viar & 358 & \\
\hline 5 & Kawasaki & 1.509 & \\
\hline 6 & Lain-lain & 116 & \\
\hline \multicolumn{2}{|c|}{ Total } & 104.682 & \\
\hline
\end{tabular}

Sumber : Samsat Kota Padang (2016)

Dari data tabel diatas dapatlah gambaran penjualan motor di Kota Padang mulai dari bulan Agustus 2015 sampai Agustus 2016, yang berjumlah 104.682 unit.

Berdasarkan latar belakang masalah diatas, maka penulis merumuskan beberapa masalah sebagai berikut:

1. Bagaimanakah pengaruh harga terhadap keputusan pembelian konsumen pada pengguna sepeda motor Pulsar kawasaki ?

2. Bagaimanakah pengaruh kualitas produk terhadap keputusan pembelian konsumen pada pengguna sepeda motor Pulsar kawasaki ?

\section{LANDASAN TEORI}

\section{Keputusan Pembelian}

\section{Faktor-Faktor yang Mempengaruhi Keputusan Pembelian}

Perilaku pembelian dipengaruhi oleh internal konsumen yang meliputi: faktor budaya konsumen, tingkat social dan karakteristik pribadi atau individu (Kotler\&Keller, 2009:166)

Adapun faktor-faktor perilaku konsumen yang mempengaruhi pembelian produk menurut Suryani (2008 : 95) adalah sebagai berikut :produk, harga, promosi dan place.

\section{Indikator dari Keputusan Pembelian}

1. Indikator Keputusan Pembelian menurut Kotler dan Amstrong (2004:227) dibedakan menjadi tiga yaitu :

a. Kemantapan pada sebuah produk yaitu keputusan yang mantap untuk membeli sebuah produk.

b. Kesesuaian dengan kebutuhan yaitu keputusan yang di ambil sesuai dengan kebutuhan yang diinginkan.

c. Memberikan rekomendasi kepada orang lain yaitu keputusan dalam setelah mencoba produk dan memberikan kepada orang lain untuk mencoba produk tersebut.

2. Pemilihan Produk

Indikator kualitas produk dalam bukunya Tjiptono (2002:25) antara lain:

a. Kinerja (Performance) merupakan karakteristik operasi dan produk inti (core product) yang dibeli. 
b. Ciri-ciri atau keistimewaan tambahan (Features) yaitu karakteristik sekunder atau pelengkap.

c. Kesesuaian dengan Spesifikasi (Conformance to spesification) yaitu sejauh mana karakteristik desain dan operasi memenuhi standar yang telah ditetapkan sebelumnya.

d. Keandalan (Realibility) yaitu kemungkinan kecil akan mengalami kerusakan atau gagal pakai.

e. Daya tahan (Durability) berkaitan dengan berapa lama produk tersebut dapat terus digunakan. Dimensi ini mencakup umur teknis maupun umur ekonomis.

f. Estetika (Easthetica) yaitu daya tarik produk terhadap panca indera.

3. Pemilihan Merk

Indikator Merk menurut (Tjiptono, 2002:106), yaitu sebagai berikut:

a. Merek harus khas atau unik

b. Merek harus menggambarkan sesuatu mengenai manfaat produk dan pemakainya

c. Merek harus menggambarkan kualitas produk

d. Merek harus mudah diucapkan, dikenali, dan diingat

e. Merek tidak boleh mengandung arti yang buruk di negara dan dalam bahasa lain

f. Merek harus dapat menyesuaikan diri dengan produk-produk baru yang mungkin ditambahkan ke dalam lini produk.

\section{Harga}

\section{Strategi Penetapan Harga} sebagai berikut:

Faktor-faktor yang memepengaruhi sensitifitas harga dapat diidentifikasi

a. Pengaruh nilai yang unik yaitu pembeli kurang sensitif terhadap harga jika produk tersebut unik.

b. Pengaruh kesadaran atas produk pengganti yaitu pembeli semakin kurang sensitif terhadap harga jika mereka tidak menyadari adanya produk pengganti.

c. Pengaruh perbandingan yang sulit yaitu pembeli akan semakin kurang sensitif terhadap harga jika mereka tidak dapat dengan mudah membandingkan mutu barang pengganti.

d. Pengaruh pengeluaran total yaitu pembeli semakin kurang sensitif terhadap harga dengan semakin rendahnya pengeluaran mereka dibandingakn dengan pendapatannya

e. Pengaruh manfaat akhir yaitu pembeli semakin sensitif terhadap harga dengan semakin rendahnya pengeluaran tersebut dibanding biaya total produk akhirnya

f. Pengaruh biaya yang dibagi yaitu pembeli akan semakin kurang sensitif terhadap harga jika sebagian biaya ditanggung pihak lain.

g. Pengaruh Investasi Tertahan yaitu pembeli semakin kurang sensitif terhadap harga jika produk tersebut digunakan bersama dengan aktiva yang telah dibeli sebelumnya. 
h. Pengaruh Harga - Mutu yaitu pembeli semakin kurang sensitif dengan harga jika produk tersebut dianggap memiliki mutu yang lebih baik, prestise, atau eksklusivitas.

i. Pengaruh Persediaan yaitu pembeli semakin kurang sensitif terhadap harga jika mereka tidak dapat menyimpan produk tersebut.

\section{Kualitas Produk}

\section{Persepsi Kualitas}

Pengertian persepsi kualitas menurut Kotler (2009) adalah persepsi pelanggan terhadap keseluruhan atau keunggulan suatu produk atau jasa layanan berkaitan dengan maksud diharapkan. Ada lima keuntungan persepsi kualitas, yaitu :

1. Alasan membeli, Persepsi kualitas sebuah merk memberikan alasan yang penting untuk membeli, hal ini mempengaruhi merek-merek mana yang harus dipertimabangkan dan selanjutnya mempengaruhi merek apa yang akan dipilih.

2. Diferensiasi, Artinya suatu karakteristik penting dari merek adalah posisi dimensi persepsi kualitas.

3. Harga Optimum, Memberikan pilihan dalam menetapkan harga optimum

4. Meningkatkan minat para distributor, Memiliki arti yang penting bagi para distributor, karena hal ini sangat membantu perluasaan distributor.

5. Perluasan merek, Persepsi kualitas dapat dieksploitasi dengan cara mengenalkan berbagai perluasaan merek, yaitu dengan mengunakan merek tertentu untuk masuk ke dalam kategori produk.

\section{Produk}

Menurut Philip Kotler \& Kevin Lane Keller (2007: 4), memberikan definisi tentang produksebagai berikut :“ produk adalah segala sesuatu yang dapat ditawarkan kedalam pasar untukdiperhatikan, dimiliki, dipakai atau dikonsumsisehingga dapat memuaskan suatu keinginan / semua kebutuhan ". Produkproduk yang dipasarkan.

Hubungan Harga Terhadap Keputusan Pembelian

Dalam jurnal yang ditulis oleh Wahid Adhiarto (2005), berjudul Analisis pengaruh produk, harga,iklan terhadapkeputusanpembelian sepeda motor honda bebek(survei di Kotamadya Magelang)menyebutkan bahwa hargamempunyai pengaruh negatif terhadap keputusan pembelian.

James C. Anderson, James B.L. Thomson \& Finn Wynstra (2000) dalam jurnal

yang berjudul "Combining Value and Price to make Purchase Decisions in Business Markets", menyebutkan bahwa "value and price appear to underlie purchasing managers' decisions". Nilai dan harga tampak mendasari para manajer dalam keputusan pembelian.

Hal ini menegaskan bahwa variabel harga berbanding terbalik dengan permintaan, jika harga naik permintaan turun, sedangkan jika harga turun permintaan naik.

Hasil hipotesis menyatakan bahwa" diduga harga berpengaruh positif dan signifikan terhadap keputusan pembelian. 


\section{Hubungan Kualitas Produk Terhadap Keputusan Pembelian}

Hal ini diperkuat oleh Ries (2000:51), yang mengatakan bahwa kualitas produk akan menjadi pertimbangan penting bagi pembelian. Rodoula Tsiotsou (2005), dalam jurnal penelitian yang berjudul Perceived Quality Levels and their Relation to Invovement, Satisfaction, and Purchase Intention menjelaskan bahwa kualitas produkmerupakan hal terpenting didalam membangun pemasaran global, baik tidaknya suatu perusahaan dinilai dari apa yang dihasilkan.

Tingkatan kualitas produk sangat berpengaruh dalam memberikan kepuasan serta keputusan pembelian. Dalam jurnal yang ditulis oleh Lukmanul Hakim (2005)berjudul“"Analisis Pengaruh Harga, Merek Dan Kualitas Produk Terha dap Keputusan Konsumen Dalam Membeli Bola Lampu Philips Di Kecamatan Medan Johor", menegaskan bahwa Kualitas Produk berpengaruh signifikan di dalam mempengaruhi keputusan pembelian.

\section{METODOLOGI PENELITIAN}

\section{Jenis Penelitian}

Jenis metode yang dipakai peneliti dalam melakukan penelitian yaitu jenis penelitian deskriptif kuantitatif Adapun desain penelitian tersebut adalah :Variabel bebas yang digunakan dalam penelitian oleh penulis yaitu harga dan kualitas

\section{Populasi}

(Ferdinand, 2006). Populasi dari penelitian ini adalah pengguna produk sepeda motor Kawasaki dengan merek pulsar 200NS di Kota Padang.

\section{Sampel}

Menurut Uma Sekaran (2006), sampel adalah sub kelompok atau sebagian dari populasi, dengan mempelajari sampel peneliti akan mampu menarik kesimpulan yang dapat digeneralisasikan terhadap (atau dapat mewakili) populasi penelitian, maka untuk menentukan ukuran sampel penelitian dari populasi tersebut dapat di gunakan rumus menurut (Rao Purba, dalam Hamdal, 2010:34) yaitu:

$$
\begin{aligned}
& \mathrm{n}=\frac{\mathrm{z}^{2}}{4(\mathrm{moe})^{2}} \\
& \mathrm{n}=\frac{(1.96)^{2}}{4(0.1)^{2}}
\end{aligned}
$$

$\mathrm{n}=96.6$ dibulatkan 97

Berdasarkan rumus diatas dapat diambil sampel minimum dari populasi yang banyak sebesar 97 orang responden pengguna produk sepeda motor Kawasaki dengan merek Pulsar 200 NS. Untuk memudahkan penelitian ini, maka diambil sampel sebanyak 100 responden.

pengambilan sampel dilakukan dengan menggunakan Non-probability Sampling (sampel non-probabilitas). Alasan menggunakan sampel non probabilitas ini adalah tidak diketahui jumlah populasi penelitian, yaitu jumlah jumlah orang-orang yang memiliki sepeda motor Kawasaki pulsar 200 NS

Adapun jumlah sampel yang digunakan dalam penelitian ini adalah sebanyak 100 orang. 


\section{Jenis Dan Sumber Data}

Dalam penelitian ini menggunakan sumber data primer dan sekunder. data primer bersumber dari penyebaran angket secara langsung kepada para responden di Kota Padang. sedangkan, data sekunder bersumber dari studi pustaka melalui berbagai jurnal, artikel majalah pemasaran, maupun artikel yang diambil dari internet.

\section{Teknik Pengumpulan Data}

Teknik pengumpulan data dalam penelitian ini menggunakan teknik angket atau kuesioner. Menurut Sugiono (2005) "Kuesioner merupakan teknik pengumpulan data yang dilakukan dengan cara memberi seperangkat pertanyaan atau pernyataan tertulis kepada responden untuk dijawabnya".

Adapun kuesioner ini disusun berdasarkan skala likert dengan menggunakan alternatif jawaban yaitu Sangat Tidak Setuju, Tidak Setuju, Ragu ragu, Setuju, Sangat Setuju.

Dengan menggunakan skala likert, maka variabel yang akan diukur dijabarkan menjadi pernyataan dan untuk keperluan analisis kuantitatif, maka jawaban diberi skor atau nilai yaitu : alternatif Jawaban Sangat tidak setuju bobot $=1$, Tidak setuju bobot $=2$, Ragu - ragu bobot $=3$, Setuju bobot $=4$, Sangat setuju $=5$

\section{Defenisi Operasional Variabel}

\section{Tabel 2}

Defenisi Operasional Variabel

\begin{tabular}{|c|c|c|c|}
\hline Variable & Konsep Variabel & Indikator & Skala \\
\hline \multirow[t]{3}{*}{ Harga (X1) } & \multirow{3}{*}{$\begin{array}{l}\text { Harga adalah Sejumlah uang } \\
\text { (ditambah beberapa barang kalau } \\
\text { mungkin) yang dibutuhkan untuk } \\
\text { mendapatkan sejumlah kombinasi } \\
\text { dari barang serta pelayanannya } \\
\text { Swasta (2001) }\end{array}$} & - Potongan & \multirow[t]{3}{*}{ Likert } \\
\hline & & - Tingkat Harga & \\
\hline & & - Capability & \\
\hline \multirow[t]{7}{*}{ Produk (X2) } & \multirow{7}{*}{$\begin{array}{l}\text { Produk adalah setiap apa saja } \\
\text { yang ditawarkan di pasar untuk } \\
\text { mendapatkan perhatian, } \\
\text { permintaan, pemakaian atau } \\
\text { konsumsi yang dapat memenuhi } \\
\text { keinginan atau kebutuhan. Kotler } \\
\text { (2009) }\end{array}$} & . Kinerja & \multirow[t]{7}{*}{ Likert } \\
\hline & & - Daya Tahan & \\
\hline & & - Kesesuaian & \\
\hline & & Fitur & \\
\hline & & - Reliabilitas & \\
\hline & & Estetika & \\
\hline & & - Kesan Kualitas & \\
\hline \multirow{4}{*}{$\begin{array}{l}\text { Keputusan } \\
\text { Pembelian } \\
\text { Konsumen } \\
\text { (Y) }\end{array}$} & \multirow{4}{*}{$\begin{array}{l}\text { Keputusan pembelian adalah } \\
\text { proses pengintegrasian yang } \\
\text { mengkombinasikan pengetahuan } \\
\text { untuk mengevaluasi dua atau } \\
\text { lebih perilaku alternatif dan } \\
\text { memilih salah satu diantaranya. } \\
\text { Hasil dari proses pengintegrasian } \\
\text { ini adalah suatu pilihan yang } \\
\text { disajikan secara kognitif sebagai } \\
\text { keinginan perilaku. Setiadi (2003) }\end{array}$} & - Kepentingan & \multirow[t]{4}{*}{ Likert } \\
\hline & & Pembelian & \\
\hline & & $\begin{array}{l}\text { - Pemilihan } \\
\text { Produk }\end{array}$ & \\
\hline & & $\begin{array}{l}\text { - Pemilihan } \\
\text { Merek }\end{array}$ & \\
\hline
\end{tabular}




\section{Penguji Instrumen \\ Uji Validitas}

Uji validitas digunakan untuk mengukur sah atau valid tidaknya suatu kuesioner. Uji validitas merupakan ukuran yang menunjukkan tingkat kevalidan suatu instrument atau kuisioner. Instrumen yang valid berarti alat ukur yang digunakan untuk mendapatkan data (mengukur) itu valid. Valid berarti instrumen tersebut dapat digunakan untuk mengukur apa yang seharusnya diukur ( Sugiyono, 2005). Suatu kuesioner dikatakan valid jika pertanyaan pada kuesioner mampu untuk mengungkapkan sesuatu yang akan diukur oleh kuesioner tersebut (Ghozali, 2007:49). Pengujian validitas tiap butir digunakan analisis item, yaitu mengkorelasikan skor tiap butir dengan skor total yang merupakan jumlah tiap skor butir (corrected item total correlation) dan nilainya dapat dilihat pada hasil pengolahan menggunakan program SPSS pada tabel item-total statistic di kolom corrected item-total correlation. Validnya sebuah item ditentukan dari nilai koefisien korelasi yang dihasilkan besar dari 0,30 dan dapat digunakan untuk analisis selanjutnya.

\section{Uji Reliabilitas}

Menurut Ghozali (2007:45), reliabilitas sebenarnya adalah alat untuk mengukur suatu kuesioner yang merupakan indikator dari suatu variabel atau konstruk. Secara umum uji reliabilitas didefinisikan sebagai rangkaian uji lanjutan untuk menilai kehandalan dari item-item pertanyaan yang valid yang dilihat dari nilai cronbach alpha yang dihasilkan > 0,60 (Sugiono, 2005). Suatu kuesioner, dapat dikatakan reliabel atau handal jika jawaban seseorang terhadap pernyataan adalah konsisten atau stabil dari waktu ke waktu. Pengukuran reliabilitas dapat dilakukan dengan dua cara yaitu:

1. Repeated measure atau pengukuran ulang : disini seseorang akan disodori pertanyaan yang sama dalam waktu yang berbeda, dan kemudian dilihat apakah ia tetap konsisten dengan jawabannya.

2. One shot atau pengukuran sekali saja : disini pengukurannya hanya sekali dan kemudian hasilnya dibandingkan dengan pertanyaan lain atau mengukur korelasi antar jawaban pertanyaan. SPSS memberikan fasilitas untuk mengukur reliabilitas dengan uji statistik Cronbach Alpha. Suatu variabel dikatakan reliabel jika memberikan nilai Cronbach Alpha >0,60.

\section{Teknik Analisis Data}

Untuk menganalisis data dan pengujian hipotesis, penelitian ini akan menggunakan beberapa teknik analisis statistik melalui pemanfaatan Statistical Package for Social Science (SPSS) versi 16-0 for windows antara lain adalah :

\section{Analisis Kualitatif}

Analisis kualitatif adalah analisis yang berupa uraian yang bersifat keterangan untuk membentuk, menyesuaikan hasil analisis kuantitatif, maka data kualitatif umumnya dikuantitatifkan agar dapat diproses lebih lanjut yaitu dengan cara mengklasifikasikan dalam bentuk kategori. 


\section{Uji Asumsi Klasik \\ Uji Normalitas}

Uji normalitas dilakukan untuk mengetahui apakah dalam model variabel bebas dan terikat keduanya bebas dan berdistribusi normal. Model yang baik bila memiliki distribusi data normal atau mendekati normal.

\section{Uji Multikolinearitas}

Uji Multikolinearitas bertujuan untuk menguji apakah model regresi ditemukan adanya korelasi antar variabel independen. Model regresi yang baik seharusnya tidak terjadi korelasi diantara variabel (Ghozali, 2001). Prasyarat yang harus terpenuhi dalam model regresi adalah tidak adanya multikolinearitas. Ada beberapa metode pengujian yang bisa digunakan diantaranya yaitu 1) dengan melihat nilai inflation factor (VIF) pada model regresi, 2) dengan membandingkan nilai koefisien determinasi individual (r2) dengan nilai determinasi secara serentak (R2), dan 3) dengan melihat nilai eigenvalue dan condition index. Pada pembahasan ini akan dilakukan uji multikolinearitas dengan melihat nilai inflation factor (VIF) pada model regresi dan membandingkan nilai koefisien determinasi individual (r2) dengan nilai determinasi secara serentak (R2). Menurut Santoso (2001), pada umumnya jika VIF lebih besar dari 5, maka variabel tersebut mempunyai persoalan multikolinearitas dengan variabel bebas lainnya.

\section{Uji Heteroskedastisitas}

Uji heteroskedastisitas bertujuan menguji apakah dalam model terjadi ketidaksamaan varians dari residual satu pengamatan ke pengamatan yang lain. Jika varians dari residual satu pengamatan ke pengamatan lain tetap, maka disebut homoskedastisitas dan jika berbeda disebut heteroskedastisitas. Model yang baik adalah yang homoskedastisitas atau tidak terjadi heteroskedastisitas (Ghozali, 2001).

\section{Uji Regresi Berganda}

Analisis regresi berganda digunakan untuk mengetahui pengaruh satu varibel terikat dengan beberapa variabel bebas. Persamaan umum regresi yang menggunakan lebih dari satu variabel bebas menurut Algifari (1997 : 52) sebagai berikut :

$$
\begin{aligned}
& \mathrm{Y}=\alpha+\mathrm{b} 1 \times 1+\mathrm{b} 2 \times 2 \\
& \text { Dimana } \\
& \mathrm{Y}=\text { keputusan pembelian kosumen } \\
& \alpha=\text { nilai } \mathrm{Y} \text { (Konstanta) } \\
& \mathrm{X} 1=\text { harga } \\
& \mathrm{X} 2=\text { produk } \\
& \mathrm{b} 1=\text { koofisien variabel } \mathrm{X} 1 \\
& \mathrm{~b} 2=\text { koofisien variabel } \mathrm{X} 2
\end{aligned}
$$

Dalam analisis regresi berganda terdapat Koefisien determinasi (R2) yaitu digunakan untuk mengetahui prosentase pengaruh semua variabel bebas terhadap nilai variabel terikat. Besarnya koefisien determinasi dari 0 sampai dengan 1, semakin mendekati 0 besarnya koefisien determinasi suatu persamaan regresi, maka semakin kecil pengaruh semua variabel bebas terhadap nilai variabel terikat. Sebaliknya, semakin mendekati 1 besarnya koefisien determinasi 
suatu persamaan regresi, maka semakin besar pula pengaruh semua variabel bebas terhadap variabel terikat.

\section{Koefisien Determinasi $\left(\mathbf{R}^{2}\right)$}

Koefisien determinan $\left(\mathrm{R}^{2}\right)$ dimaksudkan untuk mengetahui tingkat ketepatan paling baik dalam analisis regresi, dimana hal yang ditunjukkan oleh besarnya koefisiensi determinasi $\left(\mathrm{R}^{2}\right)$ antara 0 (nol) dan 1 (satu). Koefisien determinasi $\left(\mathrm{R}^{2}\right)$ nol variabel independen sama sekali tidak berpengaruh terhadap variabel dependen. Apabila koefisien determinasi semakin mendekati satu, maka dapat dikatakan bahwa variabel independen berpengaruh terhadap varibel dependen.

\section{Uji F}

Uji F digunakan untuk mengetahui pengaruh semua variabel bebas secara bersama-sama terhadap nilai variabel terikat. Pengujian ini dilakukan dengan membandingkan nilai $\mathrm{F}$ hitung dengan $\mathrm{F}$ tabel. Jika $\mathrm{F}$ hitung $>\mathrm{F}$ tabel, maka H0 ditolak dan Ha diterima. Artinya variabel bebas secara bersama-sama mempunyai pengaruh terhadap variabel terikat, dan jika $F$ hitung $<F$ tabel maka variabel bebas secara bersama-sama tidak mempunyai pengaruh terhadap variabel terikat. F tabel dicari dari tingkat kepercayaan $(\alpha)$ dan derajat kebebasan $(\mathrm{k}, \mathrm{n}-\mathrm{K}-1)$.

Pengujian signifikasi koefisien regresi dengan uji F. Pengujian ini dimaksud untuk mengetahui apakah kedua variabel tersebut secara bersama-sama mempengaruhi minat konsumen . Pengujian ini akan dilakukan dengan menguji $\mathrm{F}$ pada tingkat kepercayaan $95 \%(\alpha=0,05)$ dan derajat kebebasan tertentu, sehingga dengan pengujian uji $\mathrm{F}$ ini akan diketahui hubungan variabel independent (X) dengan variabel dependent $(\mathrm{Y})$. Fhitung dapat digunakan dengan rumus sebagai berikut :

$$
\text { Fhitung }=\mathrm{R} 2 / \mathrm{k}=\quad \mathrm{R}^{2} / \mathrm{k}
$$

$$
\overline{(1-\mathrm{R} 2) /(\mathrm{n}-\mathrm{k}-1)}
$$

Dimana $: \mathrm{R}^{2}=$ Koefisien determinasi

$\mathrm{n}=$ Jumlah data dan kasus

$\mathrm{k}=$ Jumlah variable independent

\section{Uji T}

Koefisien regresi bertujuan untuk mengetahui apakah variabel bebas yang terdapat dalam persamaan secara individu berpengaruh terhadap nilai variabel terikat. Caranya adalah dengan melakukan pengujian hipotesis terhadap koefisien regresi semua variabel bebas. Langkah-langkah analisis dalam pengujian hipotesis terhadap koefisien regresi adalah sebagai berikut :

1) Perumusan hipotesis

Ho : $b=0$, tidak terdapat hubungan fungsional yang disiknifikan antara variable X1 dan X2

Ha $: \mathrm{b}=0$, terdapat hubungan fungsional yang signifikan antara variable X1dan X2, dengan variable Y.

2) Pengujian signifikasi antara variabel

a) Pengujian signifikasi antara variabel harga terhadap keputusan pembelian konsumen.

Hipotesis yang diuji : 
Ho $: b=0$

$\mathrm{Ha}: \mathrm{b} \neq 0$

Dari hasil hipotesis ini, pada tingkat kepercayaan dan derajat kebebasan tertentu akan dipeoleh hasil $t$ hitung dan $t$ tabel, sehingga dapat disimpulkan pengaruh antara variabel independent (harga) dengan variabel dependent (keputusan pembelian konsumen)

b) Pengujian signifikasi antara variabel produk terhadap keputusan pembelian konsumen.

Hipotesis yang diuji :

Ho $: b=0$

$\mathrm{Ha}: \mathrm{b} \neq 0$

Dari hasil hipotesis ini, pada tingkat kepercayaan dan derajat kebebasan tertentu akan diperoleh hasil t hitung dan t tabel, sehingga dapat disimpulkan pengaruh antara variabel independent (produk) dengan variabel dependent (keputusan pembelian).

\section{ANALISIS DAN PEMBAHASAN \\ Analisis Regresi Linier Berganda}

Analisis regresi linear berganda digunakan dalam penelitian ini dengan tujuan untuk mengetahui ada tidaknya pengaruh variabel independen terhadap variabel dependen.Ringkasan hasil pengolahan data dengan menggunakan program SPSS for Windows versi 16.0.adalah sebagai berikut:

\section{Tabel 3}

Ringkasan Hasil Regresi

\begin{tabular}{|c|c|c|c|c|c|}
\hline \multirow[b]{2}{*}{ Model } & \multicolumn{2}{|c|}{$\begin{array}{l}\text { Unstandardized } \\
\text { Coefficients }\end{array}$} & \multirow{2}{*}{$\begin{array}{c}\begin{array}{c}\text { Standardized } \\
\text { Coefficients }\end{array} \\
\text { Beta }\end{array}$} & \multirow[b]{2}{*}{$\mathrm{T}$} & \multirow[b]{2}{*}{ Sig. } \\
\hline & B & Std. Error & & & \\
\hline $1 \quad$ (Constant) & .389 & .274 & & 1.419 & .159 \\
\hline X1 & .240 & .087 & .207 & 2.775 & .007 \\
\hline $\mathrm{X} 2$ & .629 & .072 & .650 & 8.719 & .000 \\
\hline
\end{tabular}

la. Dependent Variable: Y

Sumber: Data primer yang diolah, 2016

Berdasarkan hasil tersebut apabila ditulis dalam bentuk persamaan regresinya adalah sebagai berikut:

$$
\begin{aligned}
& \mathrm{Y}=0,389+0,240 \mathrm{X}_{1}+0,629 \mathrm{X}_{2} \\
& \text { Dimana: } \\
& \mathrm{X} 1=\text { Harga } \\
& \mathrm{X} 2=\text { Produk } \\
& \mathrm{Y}=\text { Keputusan Pembelian }
\end{aligned}
$$

Persamaan regresi berganda tersebut dapat dijelaskan sebagai berikut:

- Variabel Harga $\left(\mathrm{X}_{1}\right)$ memiliki koefisien sebesar 0,240. Ini menunjukkan bahwa variabel harga berpengaruh positif terhadap variabel keputusan pembelian. 
- Variabel Produk $\left(\mathrm{X}_{2}\right)$ memiliki koefisien sebesar 0,629. Ini menunjukkan bahwa variabel produk berpengaruh positif terhadap variabel keputusan pembelian.

\section{Koefisien Determinasi $\left(\mathbf{R}^{2}\right)$}

Koefisien determinasi ini digunakan untuk mengetahui seberapa besar variabel-variabel bebas memiliki pengaruh terhadap variabel terikatnya. Nilai koefisien determinasi untuk variabel bebas lebih dari 2 digunakan adjusted $R$ square, sebagai berikut:

\section{Tabel 4}

Koefisien Determinasi

Model Summary

\begin{tabular}{|l|r|r|r|r|}
\hline Model & $\mathrm{R}$ & R Square & $\begin{array}{c}\text { Adjusted R } \\
\text { Square }\end{array}$ & $\begin{array}{c}\text { Std. Error of the } \\
\text { Estimate }\end{array}$ \\
\hline 1 & $.778^{\mathrm{a}}$ & .605 & .597 & .53625 \\
\hline
\end{tabular}

a. Predictors: (Constant), X2, X1

Sumber: Data primer yang diolah, 2016

Hasil perhitungan dengan menggunakan program SPSS for Windows versi 16.0 dapat diketahui bahwa koefisien determinasi (adjusted $R^{2}$ ) yang diperoleh sebesar 0,597. Hal ini berarti 50\% keputusan pembelian dapat dijelaskan oleh variabel harga dan produk. Sedangkan sisanya yaitu 50\% (100\% $50 \%$ ) keputusan pembelian dipengaruhi oleh variabel-variabel lainnya yang tidak diteliti dalam penelitian ini.

\section{Uji Hipotesis}

\section{Uji Paramater Secara Individual (Uji t)}

Uji t yaitu suatu uji untuk mengetahui signifikansi pengaruh variabel bebas secara parsial atau individual terhadap variabel terikat. Hasil uji t pada penelitian ini dapat dilihat pada tabel berikut ini:

\section{Tabel 5}

\section{Hasil Uji t}

\begin{tabular}{|ll|r|r|r|r|r|}
\hline \multirow{2}{*}{ Model } & \multicolumn{2}{|c|}{$\begin{array}{c}\text { Unstandardized } \\
\text { Coefficients }\end{array}$} & $\begin{array}{l}\text { Standardized } \\
\text { Coefficients }\end{array}$ & & \\
\cline { 2 - 6 } & \multicolumn{1}{c|}{ B } & Std. Error & \multicolumn{1}{c|}{ Beta } & \multicolumn{1}{c|}{$\mathrm{t}$} & Sig. \\
\hline $1 \quad$ (Constant $)$ & .389 & .274 & & 1.419 & .159 \\
X1 & .240 & .087 & .207 & 2.775 & .007 \\
X2 & .629 & .072 & .650 & 8.719 & .000 \\
\hline
\end{tabular}

a. Dependent Variable: Y

Sumber: Data primer yang diolah, 2016

Untuk meningkatkan keputusan pembelian berdasarkan kerangka penelitian yang disertai hasil analisis regresi dan koefisien determinasi maka dapat dijelaskan sebagai berikut:

a. Keputusan pembelian dipengaruhi variabel layanan (X1). Berdasarkan hasil analisis regresi menunjukkan bahwa keputusan pembelian dipengaruhi variabel harga dengan koefisien sebesar 0,240. Sedangkan hasil uji t dengan SPSS 
diperoleh nilai signifikansi 0,007 . Dengan menggunakan batas signifikansi 0,05 nilai signifikansi tersebut berada di bawah taraf $5 \%$ yang berarti variabel harga berpengaruh signifikan positif terhadap keputusan pembelian.

b. Keputusan pembelian dipengaruhi variabel produk (X2). Berdasarkan hasil analisis regresi menunjukkan bahwa keputusan pembelian dipengaruhi variabel produk dengan koefisien sebesar 0,629. Sedangkan hasil uji t dengan SPSS for windows versi 16.0 diperoleh nilai signifikansi 0,000. Dengan menggunakan batas signifikansi 0,05 nilai signifikansi tersebut berada di bawah taraf 5\% yang berarti variabel produk berpengaruh signifikan positif terhadap keputusan pembelian.

\section{Uji Goodness of Fit (Uji F)}

Uji F dalam penelitian ini menggunakan uji ANOVA. Uji ini dapat digunakan untuk mengetahui pengaruh bersama-sama (simultan) variabel bebas (harga dan produk) terhadap variabel terikat (keputusan pembelian). Dasar pengambilan keputusannya adalah sebagai berikut:

- Jika F hitung lebih besar dari F tabel atau angka signifikan kurang dari 0,05 artinya secara simultan variabel bebas (harga dan produk) berpengaruh signifikan terhadap variabel terikat (keputusan pembelian).

- Jika F hitung lebih kecil dari F tabel atau angka signifikan lebih dari 0,05 artinya secara simultan variabel bebas (harga dan produk) tidak berpengaruh signifikan terhadap variabel terikat (keputusan pembelian).

Hasil perhitungan uji $\mathrm{F}$ dapat dilihat pada tabel berikut

\section{Tabel 6}

Hasil Uji F

ANOVA $^{\text {b }}$

\begin{tabular}{|l|r|r|r|r|r|}
\hline Model & Sum of Squares & Df & Square & F & Sig. \\
\hline 1 Regression & 42.706 & 2 & 21.353 & 74.257 & $.000^{\mathrm{a}}$ \\
Residual & 27.893 & 97 & .288 & & \\
Total & 70.600 & 99 & & & \\
\hline
\end{tabular}

a. Predictors: (Constant), X2, X1

b. Dependent Variable: Y

Sumber: Data primer yang diolah, 2016

Pengujian pengaruh variabel bebas secara bersama-sama terhadap variabel terikatnya dilakukan dengan menggunakan uji F. Hasil perhitungan statistik menunjukkan nilai signifikansi sebesar $0,000<0,05$. Artinya secara simultan variabel bebas (harga dan produk) berpengaruh signifikan terhadap variabel terikat (keputusan pembelian).

\section{PEMBAHASAN}

\section{Pengaruh harga terhadap keputusan Pembelian}

Hasil uji hipotesis pertama penelitian ini yang menunjukkan adanya korelasi positif dan sangat signifikan antara persepsi faktor harga dengan keputusan konsumen untuk membeli sepeda motor Pulsar 200 NS. Dari hasil 
analisis regresi diperoleh nilai thitung untuk harga sebesar 2.775 dengan signifikansi 0.007 yang menunjukan bahwa secara individu harga mempengaruhi keputusan pembelian.

Hasil penelitian ini mendukung penelitian yang dilakukan oleh Dewi (2009) dimana dalam penelitiannya mengemukakan bahwa harga memiliki pengaruh positif dan signifikan terhadap keputusan pembelian. Penelitian yang dilakukan oleh Mudji (2002) juga mengemukakan hal yang sama bahwa harga memiliki pengaruh positif dan signifikan terhadap keputusan pembelian

Dari hasil analisis dekriptif variabel penelitian diketahui bahwa rata rata tanggapan responden mengenai harga yang ditawarkan perusahaan adalah sebesar 3.34 atau memiliki persentase $66.7 \%$. Angka ini termasuk kategori cukup baik. Variabel harga yang terdiri dari tingkat harga, potongan harga/diskon, dan penetapan harga promosi. Hasil yang demikian menunjukkan bahwa tingkat harga sepeda motor Pulsar 200 NS sebagian besar sudah sesuai dengan harga pasar, sesuai dengan mutu dan kualitasnya, sehingga mudah dijangkau oleh konsumen. Meskipun rata-rata perusahaan tidak selalu memberikan potongan harga, konsumen tidak begitu mempermasalahkannya karena harga tersebut sudah cukup terjangkau oleh konsumen

\section{Pengaruh kualitas produk terhadap keputusan pembelian}

Hasil uji hipotesis kedua penelitian ini yang menunjukkan adanya korelasi positif dan signifikan antara produk dengan keputusan pembelian konsumen. Dari hasil analisis regresi diperoleh nilai tabel sebesar 8.719 dengan nilai signifikansi $0.000, r=0.778$ dan $\mathrm{r} 2=0.597$ yang menunjukkan bahwa secara individu kualitas produk mempengaruhi keputusan pembelian konsumen sebesar $59,7 \%$.

Hasil penelitian ini mendukung penelitian yang dilakukan oleh Evita (2007). Dewi (2009) dan Mudji (2002) dimana dalam penelitian mereka juga mengemukakan bahwa kualitas produk berpengaruh positif dan signifikan terhadap keputusan pembelian konsumen.

Pengaruh harga dan kualitas produk terhadap keputusan pembelian

Hasil uji hipotesis ketiga penelitian ini yang menunjukkan adanya korelasi positif dan sangat signifikan antara persepsi faktor harga dan kualitas produk dengan keputusan konsumen untuk membeli sepeda motor Pulsar 200 NS Dari hasil analisis regresi diperoleh nilai fhitung untuk sebesar 74.257 dengan signifikansi $0,000, R=0,778$ dan $R 2=0,605$, yang menunjukan bahwa secara simultan faktor harga dan kualitas produk mempengaruhi keputusan pembelian sebesar $60.5 \%$. Hal ini menunjukkan bahwa faktor harga dan kualitas produk memiliki pengaruh yang cukup besar terhadap keptusan konsumen untuk membeli sepeda motor Pulsar 200 NS.

Dari kedua variabel tersebut (harga dan kualitas produk) diketahui bahwa variabel yang paling dominan mempengaruhi keputusan pembelian adalah variabel kualitas produk. Hal ini menunjukkan bahwa kualitas produk merupakan hal yang paling berpengaruh bagi konsumen dalam mengambil keputusan untuk membeli suatu produk 


\section{SIMPULAN}

Melalui metode penelitian kuantitatif yang telah dilakukan oleh penulis dalam penelitian mengenai Pengaruh Harga dan Kualitas Produk Terhadap Keputusan Pembelian Sepeda Motor Kawasaki Pulsar 200 NS di Kota Padang, maka dapat disimpulkan sebagai berikut:

1. Berdasarkan hipotesis pertama, harga berpengaruh positif signifikan terhadap keputusan pembelian sebesar 0,240 untuk harga itu sendiri jika produk bagus konsumen tidak akan sensitive dengan harga.

2. Berdasarkan hipotesis kedua, produk berpengaruh positif signifikan terhadap keputusan pembelian sebesar 0,629 karena untuk produk itu sendiri konsumen bisa memilih alternative yang diinginkan.

\section{DAFTAR PUSTAKA}

Ali Hasan. 2008. Marketing. Media Utama. Yogyakarta.

Andika, A., \& Susanti, F. (2018). Pengaruh Marketing Mix Terhadap Keputusan Pembelian Parfum di Azzwars Parfum Lubeg Padang. https://doi.org/10.31227/osf.io/upgc3

Anwar Prabu Mangkunegara,(2002),Manajemen Sumber Daya Manusia, PT.Remaja Rosda Karya, Bandung

Assael, H. (1998). Consumer Behavior and Marketing Action 6 th edition . New York: International Thomson Publishing.

Aziz, N. (2019). Analisis Pengaruh Kualitas Produk, Harga, Promosi Terhadap Keputusan Pembelian Air Minum Dalam Kemasan (AMDK) Merek Aicos Produksi Pt. Bumi Sarimas Indonesia. https://doi.org/10.17605/OSF.IO/8XKYB

Aziz, N. (2019). Pengaruh Atribut Produk Terhadap Minat Beli Sepeda Motor Honda Dealer Amanah Lubuk Alung. https://doi.org/10.17605/OSF.IO/BNDAE

C.M. Lingga Purnama, 2003S trategi Marketing Plan PT. Gramedia Pustaka Utama, Jakarta.

Dasar-dasar Pemasaran. Edisi Bahasa Indonesia. Jilid 1 dan 2. Jakarta : Erlangga.

Djaslim Saladin, 2003, ManajemenPemasaran, Bandung:

Fandy Tjiptono, 2007, Strategi Pemasaran. Edisi ke dua, penerbit Andi, Gaspersz, Vincent. 2000. Manajemen Produktivitas Total. Cetakan Kedua. Jakarta: PT. Gramedia Pustaka Utama. 
Hendri, Ma'ruf. 2006. Pemasaran Ritel. Jakarta : PT. Gramedia Pustaka Utama.

http://www.ncbi.nlm.nih.gov/pubmed/10187246[Accessed on June 5, 2008]

Jamarnis, S., \& Susanti, F. (2019). Pengaruh Harga Dan Periklanan Melalui Internet Terhadap Keputusan Pembelian Produk Sabun Merek Lux Pada Mahasiswa STIE “KBP” Padang. https://doi.org/10.31227/osf.io/xz3d8

J. winardi. 2001. Motivasi dan Pemotivasian dalam Manajemen. Jakarta: PT

Kotler, Philip dan Keller Kevin Lane. (2007).Manajemen Pemasaran. (Edisi Kedua Belas, Jilid 2).Jakarta: Erlangga.

Kotler, Philip. 2005. Manajamen Pemasaran, Jilid 1 dan 2. Jakarta: PT. IndeksKelompok Gramedia.

Kotler, Philip. 2005. Manajamen Pemasaran, Jilid 1 dan 2. Jakarta: PT. Indeks KelompokGramedia.Rajagrafindo Persada.

Linda Karya.Engel, J.F.; et al, (1990); ConsumerBehavior, 6th ed, Chicago : The Dryden Press.Engel, JF., Blackwell, RD., \& Miniard, PW.,1993. Consumer Behavior. Seventh Edition. USA:The Dryden Press.

Marlius, D. (2017). Keputusan Pembelian Berdasarkan Faktor Psikologis Dan Bauran Pemasaran Pada PT. Intercom Mobilindo Padang. Jurnal Pundi. Volume 1. No. 1. Hal. 57-66. https://doi.org/10.31575/jp.v1i1.9

Marlius, D. (2016). Pengaruh Bauran Pemasaran Jasa Terhadap Minat Nasabah Dalam Menabung Pada Bank Nagari Cabang Muaralabuh. https://doi.org/10.31227/osf.io/vdqgx

Santoso, dan Ashari. 2005. Analisis Statistik dengan Microsoft Excel dan SPSS. Yogyakarta

Setiadi, Nugroho J. 2003. Perilaku Konsumen. Kencana. Jakarta.

Sugiono. 2006, Statistik Untuk Penelitian. Bandung

Suharsimi. 1992. Prosedur Penelitian. Rineka Cipta:Jakarta.

Susanti, F., \& Gunawan, A. C. (2019). Pengaruh Bauran Promosi Dan Harga Terhadap Keputusan Pembelian Produk Kosmetik Maybelline Di Kota Padang. https://doi.org/10.31227/osf.io/npjqh 